\title{
Archaeological Testing of Six Sites Along U.S. Highway 56 El Paso County, Texas
}

John W. Clark Jr.

Follow this and additional works at: https://scholarworks.sfasu.edu/ita

Part of the American Material Culture Commons, Archaeological Anthropology Commons, Environmental Studies Commons, Other American Studies Commons, Other Arts and Humanities Commons, Other History of Art, Architecture, and Archaeology Commons, and the United States History Commons

Tell us how this article helped you.

This Article is brought to you for free and open access by the Center for Regional Heritage Research at SFA ScholarWorks. It has been accepted for inclusion in Index of Texas Archaeology: Open Access Gray Literature from the Lone Star State by an authorized editor of SFA ScholarWorks. For more information, please contact cdsscholarworks@sfasu.edu. 


\section{Archaeological Testing of Six Sites Along U.S. Highway 56 El Paso County, Texas}

\section{Licensing Statement}

This is a work produced for the Texas Department of Transportation (TxDOT) by the report producer. TxDOT and the report producer jointly own all rights, title, and interest in and to all intellectual property developed under TXDOT's contract with the report producer. The report may be cited and brief passages from this publication may be reproduced without permission provided that credit is given to both TxDOT and the report producer. Permission to reprint an entire chapter, section, figures or tables must be obtained in advance from either the Supervisor of the Archeological Studies Branch, Environmental Affairs Division, Texas Department of Transportation, 125 East 11th Street, Austin, Texas, 78701 or from the report producer. 


\section{Archaeological Testing of Six Sites Along U.S. Highway 54 \\ E1 Paso County, Texas}

By

John W. Clark

Texas

State Department of Highways and Public Transportation

Highway Design Division

September 1981 


\section{ABSTRACT}

Six prehistoric sites along the proposed route of U.S. Highway 54 in E1 Paso County, Texas, were tested during the spring and summer of 1981. No further work is recommended at four of these sites due to the paucity of recovered materials and the general deflated and eroded nature of the sites.

Two sites are recommended for further work. Testing of Site 41EP321 produced two probable pithouse features with buried charcoal lenses and possible post holes as well as numerous varied artifacts including Mimbres Black-on-White, Chupadero Black-on-White, El Paso Brown, and El Paso Polychrome pottery types. Testing of Site $41 \mathrm{EP} 289$ produced three midden areas (areas of high surficial artifact frequency), trash pits, post molds, hearths, and artifacts including Mimbres Black-on-White, Chupadero Black-on-White, El Paso Brown, and El Paso Polychrome pottery types. The artifact types and frequencies from the two sites are identical, suggesting a contemporaneity of the sites, and can be placed within the Dona Ana phase of the Jornada Branch of the Mogollon. 
Archaeological survey along the right-of-way of the proposed northeast freeway extension (U.S. 54) in El Paso County, Texas, revealed the presence of six prehistoric archaeological sites in the most viable route for the highway. Sites were given temporary numbers from the southwest end of the project from one to six near the northeast end. Sites with field numbers 1, 2, 4, 5 and 6 were tested. Site 3 was too small for testing.

The purpose of this testing report is to provide data on the results of the testing of these particular sites. Since a report on the excavation of two of these sites will be forthcoming after the completion of the field work on those sites, a complete analysis and evaluation of previous archaeological work in the area, the environmental setting, soils, and geology are not deemed necessary for such a report. Moreover, such data would be a duplication of similar information already published in quite a number of reports from the area. 


\section{TESTING}

Site 1: This site consisted of a light scatter of ceramics on a gently sloping alluvial fan. Four $2 \times 2$ meter test pits were excavated into the site, all but one pit producing negative results. In the one test pit having artifacts, only two sherds were encountered, and these in the upper level. One test pit was excavated to a depth of $50 \mathrm{~cm}$ below the surface while the others were excavated to a depth of $40 \mathrm{~cm}$.

It appears that cultural phenomena at this site are confined to the surface and thinly scattered there. Therefore, no further work is recommended for this site.

Site 2 (41EP321): This site is a large area covering approximately 10 to 15 acres on the same alluvial fan as Sites 1, 3, 4, 5, and 6. A series of twelve $2 \times 2$ meter test pits (Fig. 1) were excavated to a depth of somewhat more than a meter below the surface, and a series of 87 auger holes were excavated. Of the 87 auger holes excavated, one revealed the presence of fire-cracked rock and 13 revealed the presence of charcoal.

A 11 testing was conducted in a relatively small area of the site north of the centerline of the proposed highway.

Cultural deposits were found to extend from the surface to a maximum depth of $40 \mathrm{~cm}$ except in two instances in which portions of pithouses were encountered. In those cases the cultural deposit extended to one meter below the surface on the interior of the pit. Comprising the cultural debris are the following artifacts:

Mimbres Black-on-White

Chupadero Black-on-White

E1 Paao Brown

Corrugated ware

E1 Paso Polychrome
Miscellaneous brownwares

Obsidian flakes and pebbles

Rhyolite flakes

Basalt flakes

Chert flakes 
Two probable pithouse features were encountered. The first was located in the 2 x 2 test pit designated N60/E0 at a depth of 25 to $30 \mathrm{~cm}$ below the present surface. Evidence consisted of an adobe wall $40 \mathrm{~cm}$ wide encountered at $30 \mathrm{~cm}$ below the surface and an interior charcoal lens encountered at $25 \mathrm{~cm}$ below the surface (Fig. 2A). The test pit was excavated only to a depth of $40 \mathrm{~cm}$ in order to retain most of the feature intact. The interior of the pithouse feature occupied $75 \%$ of the $2 \times 2$ meter test pit.

The second pithouse was encountered in Test Pit N60/E20 at $55 \mathrm{~cm}$ below the present surface (Fig. 2B). Evidence for the structure consists of a change in deposit from coarse sand and gravel to light brown sandy loam containing small gravel and charcoal flecks. Two interior charcoal lenses were encountered at depths of 55 and $75 \mathrm{~cm}$ below the surface. The feature was not excavated below $90 \mathrm{~cm}$ below the surface in order to retain the feature for future excavation. The feature occupied virtually a 11 the $2 \times 2$ meter test pit except the north 30 to $40 \mathrm{~cm}$ and a narrow area on the west side of the unit. Three apparently random stains in the floor at $90 \mathrm{~cm}$ may represent post holes.

Cultural deposits at Site 2 (41EP321) are scattered over a 10 to 15 acre area. Testing revealed buried architectural features in one area of the site. No other areas have been tested. It is, however, clear that there are significant features at the site and that additional work is needed not only in the tested area but in other areas as well.

Site 3: Cultural evidence for Site 3 consists of an eroded burned rock agglomeration and a very light scatter of ceramics. A small drainage has eroded much of the site. No testing was done at the site and none is recommended.

Site 4 (41EP289): Testing at the site consisted of a controlled surface collection and the excavation of a series of $2 \times 2$ meter test pits (Fig. 3). The surface collection indicated three midden areas (areas of high surficial artifact frequency). The concentrations were confirmed by the test excavations. Intermidden areas were also tested revealing a quite low frequency of artifacts. 
Testing was conducted in a 11 areas of the site in order to define site boundaries and areas of artifact concentration. When these were found, further excavation was made to determine the nature of the midden areas. In this way a series of buried features was located.

The deposits containing cultural debris ranged in thickness from 0 to about $30 \mathrm{~cm}$ below the surface. The following artifacts comprise the cultural debris:

Mimbres Black-on-White

Chupadero Black-on-White

El Paso Brown

Corrugated ware

El Paso Polychrome
Miscellaneous brownwares

Obsidian flakes and pebbles

Rhyolite flakes

Basalt flakes

Chert flakes

It should be noted that the artifact types and their apparent frequencies are identical at this site and Site 2.

A variety of buried archaeological features was encountered during the testing include:

Sheet midden (S25-30/W20 at $10 \mathrm{~cm}$ below the surface)

Trash pits (S30/W20, S40/E10, 15, S38/E14, S36/E12, S38/E12, and others )

Post molds (S15/W 40, S38/E 14, S38/E 12, S36/E 12)

Hearths (S15/W 34, S38/E 14, S36/E 14)

All features appeared at between 15 and $20 \mathrm{~cm}$ below the surface. All features were drawn in plan and profile and were photographed. It is clear that features are associated with midden areas.

The testing revealed intersite patterning with the largest midden areas aligned west-northwest to east-southeast and with features associated with the midden areas. No architectural features were encountered. The artifact types and frequencies are identical to Site 2 (41EP321), suggesting their contemporaneity. The lack of architecture at Site 41EP289 may suggest a difference in function. It is recommended that 
additional work be done at this site to refine the definition of site boundaries, to further define the midden areas, to explore their relationships, and to compare this site to Site 2 (41EP321).

Site 5: The site is located on the alluvial fan. Surficial indications of the presence of a site include scattered burned rock, a chert flake, and a quartzite hammerstone.

Six 2 x 2 meter test pits were excavated into this site to a maximum depth of $50 \mathrm{~cm}$. Cultural debris was found only within the upper $5 \mathrm{~cm}$ of the deposit. A shallow ash lens was located in Test Pit S4/E0. No further work is recommended at this site as the deposits appear to be severely deflated.

Site 6: Located on the edge of a blowout basin or playa, this site covers a 100 meter diameter area of thinly scattered thermally fractured limestone, a metate fragment, and a small obsidian pebble.

A series of eight test pits were excavated into the site producing a small number of fire cracked rocks and one flake in the upper $5 \mathrm{~cm}$. No other cultural features were encountered, although some units were carried down to a depth of $50 \mathrm{~cm}$. No further work is recommended. 


\section{SUMMARY}

In summary, two of six sites located on the survey of the right-of-way of the northeast freeway (U.S. 54) are considered to have sufficient cultural debris to warrant further excavation. These two sites (Sites 2 and 4, or Sites 41EP321 and 41EP289) have identical artifact inventories (insofar as any analysis has been made) but differing buried feature complexes.

Local professional archaeologists with numerous publications and longterm experience in the area have visited both sites and have examined the sherds collected from them. They suggest that the sites pertain to the Dona Ana phase of the Jornada Branch of the Mogollon (Rex Gerald and Tom C. O'Laughlin: personal communications on numerous occasions). They further indicate that this phase is poorly defined and not well represented in the previous archaeological work for the area. 
$415 p 321$
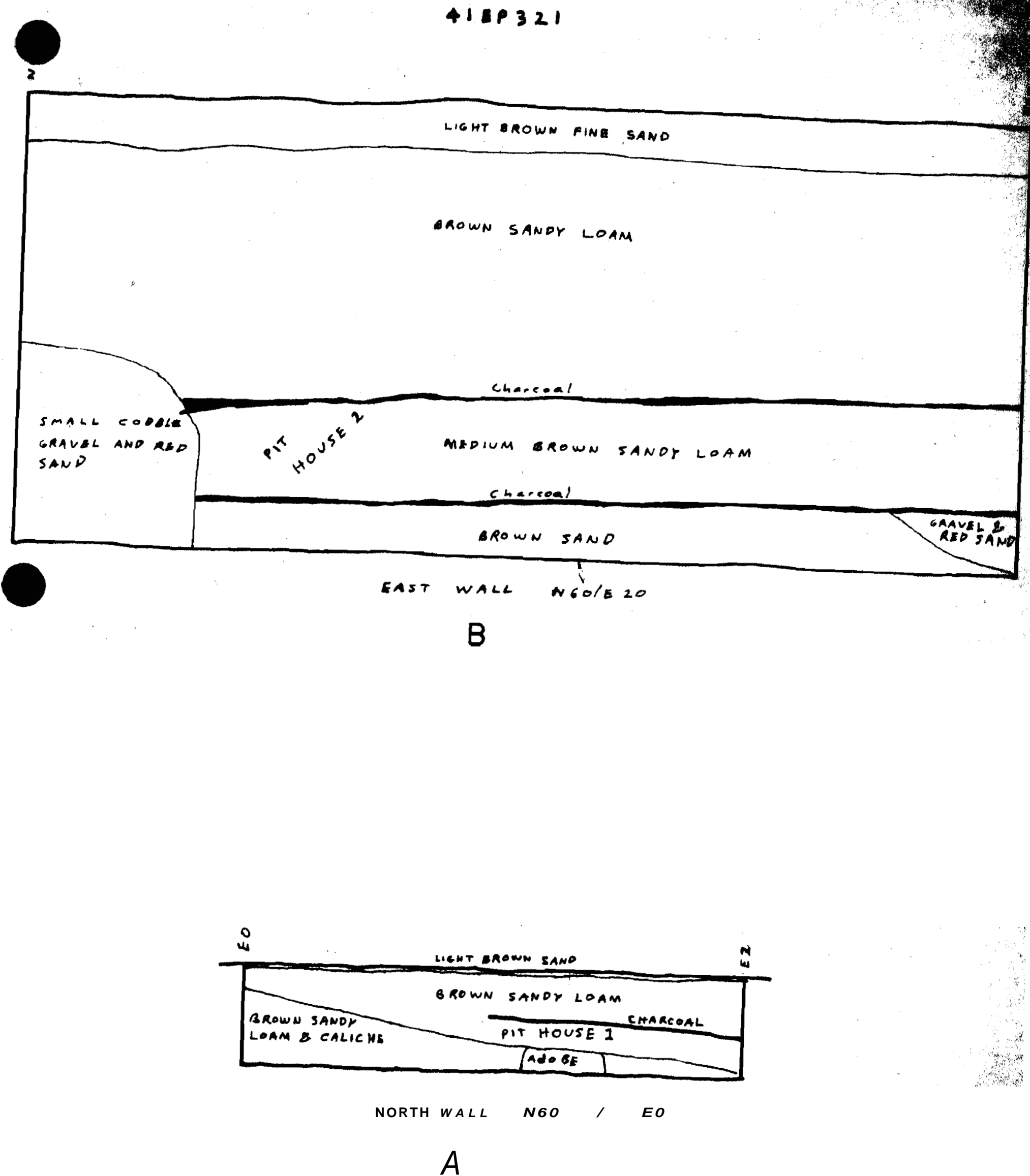

FIGURE 2 


\section{Research Design}

US Highway 54 Project

E1 Paso County, Texas

Site No. 1 (see detailed information in testing report): Four 2 x 2 test pits randomly placed in site producing essentially negative results.

Site No. 2; 41EP321 (see detailed information in testing report: Twelve $2 \times 2$ meter test pits near the center of the site and 87 auger holes finding 2 pit houses, a burned rock area, and 13 locations of buried charcoal.

Site No. 3 (see detailed testing report): No testing was done at this site due to its small size and disturbed nature.

Site No. 4; 41EP289 (see detailed testing report): A grid of 5 x 5 meter units was superimposed over the site, and a controlled surface collection was made. Using this as a base, a series of 2 x 2 meter pits was excavated - each below the cultural deposits - in order to define artifact concentrations, to determine site boundaries, and to search for indications of the type of occupation represented by the site. Hearths, trash pits, post molds, and midden areas were encountered. No pithouses were found.

Site No. 5 (see detailed testing report): Six 2 x 2 meter test units were excavated encountering a very thin and scattered (deflated) cultural deposit.

Site No. 6 (see detailed testing report): Eight test pits were excavated with negative results. 
Regarding previous research, a large number of site reports have been written on the area, many by amateurs concentrating on small partial site excavations with little view to refining the original definition of phases of the Jornada Branch of the Mogollon (Lehmer 1948). There have been, however, a number of substantial contributions by professionals. Perhaps the earliest detailed report was Moore's (1947) report on Twelve Room House.

More recently Aten's (1972) report of the testing at the Northgate Site, a pithouse site, Lynn's (1976) work at the Northeast Sewage Treatment Plant, O'Laughlin's (1979) work at Transmountain campus, and Thompson and Beckett's (1979) work on Diana Street have a 11 reported sites in northeast E 1 Paso. A more general series of survey reports (Whalen 1977, 78) focused on the patterns of site distribution by period of occupation.

Other reports for the area include those by Beckes et al. (1977) and O'Laughlin (1980). The report by Beckes et al. focuses on a survey while that of O'Laughlin deals with the Archaic Period on the west side of the city.

The principal results of the above work has been the amplification of the definitions of the Archaic Period and the Mesilla and E1 Paso phases of the Jornada Branch of the Mogollon. This work has produced a variety of testable hypotheses concerning settlement patterning, intersite patterning, economy, and utilization of aspects of the environment.

The salient feature of all the reports is the failure to either encounter or define sites of the Dona Ana phase as defined by Lehmer (1948). Lehmer's description indicates certain features and ceramic types to be expected at sites of this phase. Testing of Sites 41EP289 and 321 indicates the presence of these items.

Then, the primary questions to be addressed are: 1) Do the sites indeed represent the generally unrecognized and unreported Dona Ana Phase? 2) Is it possible to quantify the proportions of the artifact classes defining the phase? 3) Is it possible to define intersite patterns of features and middens? 4) What is the relationship of the two sites? 
There may be other questions that could be answered depending on factors of preservation. It is not expected that faunal or pollen analysis will be fruitful because of soil conditions at the sites. Bone and shell have not been seen to be preserved.

In order to address the four questions posed above the sites must contain the features described by Lehmer and must be separable from Mesilla and El Paso Phase sites. The artifact frequencies should be different from Mesilla and El Paso Phase sites and radiocarbon samples should provide dates between the aforementioned phases. Testing at Site 41EP289 has already demonstrated a patterned distribution of artifacts and features. Patterns of intersite features should be present at Site 41EP321 given sufficient aereal excavation.

At present no pithouses have been found at Site 41EP289, while at least two are present at Site 41EP321. It is suggested that Site 41EP289 may be a satellite community dependent on Site 41EP321. If this is the case, the artifact frequency, radiocarbon dating, and nonarchitectural features should be nearly identical. Site 41EP321 should, however, contain a greater number of artifacts representing permanent or near permanent occupation.

Methodologies designed to address these questions will involve extensive hand excavation to define features and artifact concentrations, architecture, and in general to assure that there is little chance that significant data are not overlooked. A number of soil-pollen samples will be taken on the hope that pollen might be preserved. Following hand excavations a number of trenches dug by a Gradall will be executed in order to test unexcavated areas and to be sure that there are no earlier deposits.

Methodologies will insure proper recording of all features, artifact proveniences, etc. Standard techniques will be used including 2 x 2 meter units laid out on a grid system excavated in $10 \mathrm{~cm}$ levels, except where stratigraphy may dictate other units. The 2 x 2 meter unit will be used to expose areas sufficient to recognize features. 
Provided clearence is given, the project will proceed for a period of five to six months utilizing six laborers and one archaeologist. At present the crew consists of four students with field school and other archaeological experience, a professional surveyor, and a nonexperienced laborer.

Excavated features encountered in the testing of Site $41 E P 289$ include burned stone hearth concentrations, shallow basin-shaped trash pits, $\mathrm{six}$ post molds averaging $12 \mathrm{~cm}$ in diameter and 10 to $15 \mathrm{~cm}$ in depth, and two midden areas as well as three major areas of artifact concentrations. These are described in the testing report and sample features are illustrated.

Features found in the testing of Site 41EP321 include two probable pit houses (see profiles in testing report) and three possible post molds in one of the houses. Auger holes produced burned rocks and charcoal areas.

Pollen samples will be submitted to Texas A\&M University in accordance with a long standing agreement.

This item obviously intends to focus on the relationship between Site 41EP289 and Site 41EP321. Should pit houses be encountered at Site 41EP289, it would tend to indicate that Site 41EP289 may not be simply a satellite of Site 41EP321. The radiocarbon samples may then provide data on contemporaneity.

With regard to settlement pattern, there is little that can be done with only two Dona Ana Phase sites. However the geographic position of the two sites may suggestive of the relationship between the patterns of earlier and later Jornada Branch sites as discussed in Whelan's works on the Hueco Bolson.

As previously discussed there is the possibility that Site 41EP289 is a satellite of Site 41EP321. If this is the case the sites should be relatively proximate (as indeed these two sites are). They are within $1 / 2$ mile of one another and appear at this time to be contemporaneous. Their 
proximity enhances the possibility that Site 41EP289 is a dependency of S i te 41EP321.

There appear to be no Archaic deposits on the sites. 
Preliminary and Incomplete List of References

Aten, Lawrence E.

1972 Evaluation of the Cultural Resources of the Northgate Site.

Texas Archeological Salvage Project Research Report 5. The University of Texas at Austin.

Beckes, Michael R., Alan R. Dalaney, John D. Pigott, Robert r. Scott, IV, and Nancy Kays Smiley

1977 A Cultural Resource Inventory and Assessment of McGregor Guided Missile Range, Otero County, New Mexico. Texas Archaeological Survey Research Report 65(II). The University of Texas at Austin.

Davis, Leslie

1967 Recent Excavations at Hot Well Site. Third Annual Regional Archaeological Symposium for Southeastern New Mexico and Western Texas. Iraan, Texas.

Jaco, Herbert

1971 Soil Survey of El Paso County, Texas. USDA Soil Conservation Service Publication Washington.

Lehmar, Donald J.

1948 The Jornada Branch of the Mogollon. University of Arizona

Bulletin 69(2) , Tucson.

Lovejoy, Earl M.P.

1980 El Paso's Geologic Past, Science Series 7. Texas Western

Press. The University of Texas at El Paso.

Lynn, Warren M.

1976 Archeological Testing at the Northeast Sewage Treatment Plant, El Paso County, Texas. Archeological Survey Report 15. Texas Historical Commission. Austin.

Moore, G.E. 1947

Twelve Room House Ruin. Bulletin of the Texas Archeological and Paleontological Society 18: 94-114. Abilene.

O'Laughlin, Thomas C.

1979 Excavations at the Transmoutain Campus, El Paso Community College, El Paso, Texas. El Paso Centennial Museum Publications in Anthropology 7. The University of Texas at El Paso.

1980 The Keystone Dam Site and Other Archaic and Formative Sites in Northwest El Paso, Texas. El Paso Centennial Museum Publications in Anthropology 8. The University of Texas at El Paso. 
Schmidt, Robert H., Jr.

1973 A Geographical Survey of Chihuahua. Texas Western Press

Monograph 37. The University of Texas at El Paso.

Thompson, Marc, and Patrick H. Beckett

1979 A Study of Prehistoric Campsites in Northeast El Paso. Cultural Resources Management Division Report 310. Department of Sociology and Anthropology, New Mexico State University. Las Cruces.

Whalen, Michael E.

1977 Settlement Patterns of the Eastern Hueco Bolson. El Paso Centennial Museum Anthropological Paper 4. The University of Texas at El Paso.

1978 Settlement Patterns of the Western Hueco Bolson. El Paso Centennial Museum Publications in Anthropology 6. The University of Texas at El Paso. 